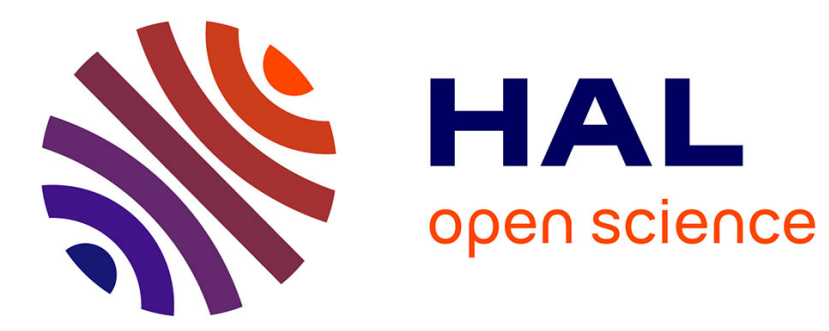

\title{
Organizational form and efficiency of franchise chains
} Isabelle Piot-Lepetit, Rozenn Perrigot, Gérard Cliquet

\section{To cite this version:}

Isabelle Piot-Lepetit, Rozenn Perrigot, Gérard Cliquet. Organizational form and efficiency of franchise chains. International Journal of Retail and Distribution Management, 2014, 42 (7), pp.671-684. 10.1108/IJRDM-04-2013-0089 . halshs-01023719

\section{HAL Id: halshs-01023719 \\ https://shs.hal.science/halshs-01023719}

Submitted on 27 May 2020

HAL is a multi-disciplinary open access archive for the deposit and dissemination of scientific research documents, whether they are published or not. The documents may come from teaching and research institutions in France or abroad, or from public or private research centers.
L'archive ouverte pluridisciplinaire HAL, est destinée au dépôt et à la diffusion de documents scientifiques de niveau recherche, publiés ou non, émanant des établissements d'enseignement et de recherche français ou étrangers, des laboratoires publics ou privés. 


\title{
Organizational form and efficiency of franchise chains ${ }^{1}$
}

\author{
Piot-Lepetit, I. ; Perrigot, R. ; Cliquet, G.
}

\section{Introduction}

Many authors analyzed performance in the retail and service industries, through the concept of efficiency (e.g., Barros, 2006; Barros and Alves, 2003; de Jorge Moreno, 2008; de Jorge Moreno and Sanz-Triguero, 2011; Mostafa, 2009; Sellers-Rubio and Mas-Ruiz, 2006; Uyar et al., 2013; Yu and Ramanathan, 2008). But still a few ones focused on the specific case of franchising even though the need for more research on performance in the franchise sector has been highlighted (Combs et al., 2011a, 2011b; El Akremi et al., forthcoming). A few papers dealt with the performance at the outlet level, by comparing franchised outlets and companyowned outlets in terms of performance (e.g., Anderson, 1984; Kosová et al., forthcoming). Others considered the performance at the chain level (e.g. Botti et al., 2009; Perrigot et al., 2009) analyzing the way chain organizational form, namely predominantly franchised chains, predominantly company-owned chains or plural form chains -- the latter being a mix of franchised outlets and company-owned outlets (Bradach and Eccles, 1989) -- may influence chain performance. Comparing the efficiency of hotel chains, Perrigot et al. (2009) showed that plural form chains were more efficient than other chain organizational forms.

However, according to Shane (1998, p. 736), "the correct question for franchising scholars to ask is [...] what is the optimal proportion of franchised units given other firm characteristics?" In this perspective, some authors demonstrated the existence of an optimal percentage of franchised (vs. company-owned) outlets within the chain. For instance, Hsu and Jang (2009) found a non-linear relationship between the percentage of franchised outlets and

\footnotetext{
${ }^{1}$ Paru dans International Journal of Retail \& Distribution Management, vol. 42, $n^{\circ}$ 7, 2014, 671-684
} 
franchise chain profitability. Based on a sample of publicly-held restaurant chains, they evaluated the optimal percentage of franchised outlets at $44 \%$ for optimizing the return on assets and $46 \%$ for optimizing the return on equity. El Akremi et al. (forthcoming) confirmed the existence of such a non-linear relationship. Based on a sample of U.S. franchise chains in the retail and service industries, they found a significant and positive impact of the percentage of franchised outlets on chain efficiency, up to an optimal rate of $62 \%$. The main shortcoming of these studies, based on econometric techniques, is that they provide a unique optimal percentage of franchised outlets for all the chains in the sample. They just partly answer to the question of Shane (1998) by identifying the "optimal proportion of franchised units". The "given other firm characteristics" part of the question is missing. Indeed, econometric techniques do not allow for identifying the optimal percentage of franchised units for each chain in the sample, taking into consideration initial chain configurations and strategies such as historical management practices that influenced the current percentage of franchised outlets of the chain and also the optimal one.

In this paper, we attempt to cover the shortcoming of previous studies by jointly analyzing the efficiency and determining the optimal percentage of company-owned outlets (PCO) of each franchise chain. To do it, we use a non-econometric technique, called Data Envelopment Analysis (DEA) and developed by management scientists upon economic concepts (Charnes et al., 1978), that has been extensively applied in performance evaluation and benchmarking (Charnes et al., 1994). DEA is used for assessing the relative efficiency of a set of observed Decision Making Units (DMUs) -- here the franchise chains -- by comparing the current production process of each DMU with the production processes of all observed DMUs. DEA allows the identification of best practices -- the efficient DMUs used by the DEA model as benchmarks. DEA also provides, for each inefficient DMU, an efficiency score, a DMUspecific set of efficient units that can be utilized as benchmarks for efficiency improvements, 
and DMU-specific targets on which action plans can be built on. Thus, the classical DEA model is a benchmarking method that considers DMUs' characteristics when enabling comparisons between DMUs to assess their efficiency. One extension provided by Banker and Morey (1986) allows the introduction of exogenous variables such as strategic variables - here, the PCO characterizing the organizational form of franchise chains -- in the DEA framework. This extended DEA model can then provide a benchmarking of franchise chain efficiency taking into account the PCO as well as the other chain characteristics. In doing so, the efficiency of franchise chains is only evaluated at their current PCO. It does not allow for an identification of the optimal PCO of each franchise chain.

In this paper, we extend the classical DEA by defining a model that enables an assessment of franchise chain efficiency along with an evaluation of its optimal PCO while taking into account for its other characteristics. Assuming that franchisors are looking for higher performance through an optimization of their $\mathrm{PCO}$, this modeling process leads to a new method of benchmarking and provides an answer to Shane's question (1998).

The empirical study concerns the French franchise sector. The sample includes 43 franchise chains in the retail and service industries. Main findings of this study are, first, that the PCO has a positive influence on the efficiency of franchise chains, even though the main explanation to inefficiencies has to be found in other chain characteristics. Second, higher efficiency level can be reached when the PCO is set at the optimal level of each chain. In the optimal organization of the franchise sector provided by our model, no more chains are fully franchised while some become fully company-owned. Between the two extremes, the average optimal PCO is at $0.44 \%$ rather than $0.32 \%$ in the sample. Furthermore, $60 \%$ of the chains should increase the number of outlets they owned while $35 \%$ should increase the number of franchised outlets in their chain. 
The paper is organized as follows. In section 2, we briefly review the franchising literature on efficiency and plural form and present research hypotheses. Section 3 describes the research design. Section 4 presents the main results of the empirical application. Implications for research and practice are then discussed in section 5. Section 6 concludes.

\section{Literature Review}

\subsection{Franchising and efficiency}

Efficiency is a key issue in the franchise sector. Many authors tackled the efficiency issue at the outlet level. For instance, Anderson et al. (1998), studying the efficiency of 184 unaffiliated real estate brokerage firms with 92 affiliated ones, concluded that both franchised and non-franchised firms operated relatively inefficiently. Yoo et al. (1998) showed the superiority of franchised outlets compared to non-franchised ones in the refreshment place industry. Empirical studies on franchised outlet efficiency have often been carried out in the hotel industry (e.g., Anderson et al., 2000; Tsaur, 2000). Main conclusions of these studies underlined the relevance of internal benchmarking within a chain. It provides franchisors with managerial recommendations useful in pointing out their best outlets and improving results of their less efficient ones.

External benchmarking may help franchisors to compare their results with those of other franchise chains and to examine variables influencing their performance. Studying the French hotel industry, Perrigot et al. (2009) concluded that plural form chains are more efficient than predominantly franchised or company-owned chains. Thus, plural form may be an important driver of chain efficiency. This is due to the symbiotic character of this organizational form based on the franchisor capacity to manage synergies between company-owned and franchised outlets (Bradach and Eccles, 1989; Bradach, 1998; Combs et al., 2011a, 2011b; 
Perryman and Combs, 2012). By using the percentage of company-owned outlets (PCO) to describe franchise chain organizational form, the following hypothesis is formulated:

H1. The PCO chosen by the franchisor has a positive impact on its chain efficiency.

\subsection{Franchising and plural form}

In the franchising literature, the advantages associated with plural form have been pointed out, mainly regarding managerial challenges. For instance, Bradach (1997) investigated plural form through an in-depth exploratory study of five U.S. fast-food chains. His findings revealed that using plural form contributes to overcome four managerial challenges: spatial expansion by adding new outlets; brand protection by maintaining concept uniformity; local reactivity to threats or opportunities and; service and/or product concept evolution for a constant adaptation to changes. Dant and Kaufmann (2003) found that strategic insight and control afforded by the plural form arrangement are richly valuable for franchisors regardless of their preference for a particular type of outlet ownership. Ehrmann and Spranger (2004) demonstrated that plural form chains can benefit from the effects of cost reduction, quality enhancement, growth stimulation, and optimized quality and risk control.

However, plural form has also some drawbacks. It could be a source of conflicts between managers of company-owned outlets and franchisees when the franchisor favors the former versus the latter, or a source of additional expenses because it entails a double management system (Cliquet, 2000; Perrigot and Herrbach, 2012). Hence, the problem is no more why do firm franchise? (Michael, 1996), or should franchise chains buy back their franchised outlets in an ownership redirection stream? (Hunt, 1973; Oxenfeldt and Kelly, 1968-69), but as raised by Shane (1998), it is rather: which is the optimal proportion of franchised/companyowned outlets within a plural form chain? 
Bradach (1998) explained that choosing plural form is not limited to simply choosing a specific percentage of company-owned outlets (PCO). The PCO results from strategic insights, and hence provides a synthesis of plural form chains' management (Dant and Kaufmann, 2003). In other words, the choice of an ideal PCO within plural form chains can influence the future of the chain regarding its strategic positioning, whereas the PCO can also be influenced by the way the chain is managed by the franchisor, and indirectly by the franchisees. Franchisors are usually aware of the relevance of maintaining a specific threshold in terms of PCO within their chain without overlooking the associated difficulties. An increasing number of franchise chains tend to choose their PCO (Caves and Murphy, 1976; Scott, 1995). Some authors insisted on the need to select the PCO in accordance with the management of plural form chains (Lafontaine and Shaw, 2005; Michael, 2000). Choosing the right PCO when managing a plural form chain is thus of high interest for franchisors when considering the efficiency of the chain. The following hypothesis is then formulated:

H2. Higher improvements in franchise chain efficiency can be achieved when the PCO is optimized.

\section{Research design}

\subsection{Methodology}

Developed by management scientists on the basis of economics concepts (Charnes et al., 1978) for benchmarking and performance analysis, the DEA model uses all observed Decision Making Units (DMUs) -- here the franchise chains -- to assess the relative efficiency of each observed DMU by comparing its productive bundle to those of all DMUs in the sample. A DMU is evaluated as efficient if neither any other observed DMU, nor any combination of observed DMUs can provide a better productive bundle. If a DMU is identified as inefficient, the DEA approach provides a score characterizing the amount of 
potential improvement that can be achieved by becoming efficient without changing the current organization of the DMU as well as benchmarks among the efficient DMUs (Charnes et al., 1994).

Assuming that there are $K$ DMUs $(k=1, \ldots, K)$ which convert $N$ inputs $(n=1, \ldots, N)$ into $M$ outputs $(m=1, \ldots, M)$, the relative efficiency score $\theta^{\circ}$ of a test DMU " $o$ " is obtained by solving the following DEA model (Charnes et al., 1994):

$$
\begin{aligned}
& \min _{\theta^{o}, z_{k}^{o}} \theta^{o} \\
& \text { s.t. } \sum_{k=1}^{K} \lambda_{k}^{o} x_{n k} \leq \theta^{o} x_{n o} \quad n=1, \ldots, N \\
& \sum_{k=1}^{K} \lambda_{k}^{o} y_{m k} \geq y_{m o} \quad m=1, \ldots, M \\
& \lambda_{k}^{o} \geq 0, \quad k=1, \ldots, K
\end{aligned}
$$

with the vector $\lambda^{o}=\left(\lambda_{1}^{o}, \ldots, \lambda_{k}^{o}, \ldots, \lambda_{K}^{o}\right)$ identifying the benchmarks of the DMU " $o$ ". $\lambda_{k}^{o}$ $(k=1, \ldots, K)$ takes a positive value when the DMU " $k$ " is a benchmark of the DMU " $o$ " and zero otherwise. A DMU is considered as efficient when its score is unity, and inefficient when its score is less than unity. In the model (1), the efficiency is assessed by means of a reduction in the amount of resources used by DMU " $o$ " as much as possible without changing its production level. Model (1) is run $K$ times for identifying the relative efficiency score of each DMU relative to all DMUs.

For implementing the DEA model defined by Banker and Morey (1986) that allows an evaluation of the efficiency of each DMU taking into account its current PCO, the following additional constraint is introduced in model (1):

$$
\sum_{k=1}^{K} \lambda_{k}^{o} P C O_{k} \leq P C O_{o}^{o b s} \quad P C O_{o}^{o b s}: \text { observed PCO }
$$


In the right-hand side of the constraint (2), the variable $P C O_{o}^{o b s}$ is the current value of the PCO chosen by the franchisor, i.e., an observation from our dataset. The direct introduction of the constraint (2) in the model (1) ensures that the efficiency of each chain is assessed relative to other chains having the same PCO; thus providing a benchmark for each chain at its observed PCO. The comparison of efficiency scores assessed with and without the constraint (2) allows us to evaluate the impact of the PCO -- chosen by the franchisor according to its strategic vision -- on the chain efficiency. The result of this comparison is used to test the hypothesis $\mathrm{H} 1$.

Following Shane's (1998) suggestion regarding the identification of the optimal proportion of franchised outlets -- respectively the optimal PCO -- given other chain characteristics, we specify a new DEA model allowing for the evaluation of the optimal PCO of each chain along with the measurement of its efficiency by introducing the following additional constraint in the model (1):

$$
\sum_{k=1}^{K} \lambda_{k}^{o} P C O_{k} \leq P C O_{o}^{\text {free }} \quad P C O_{o}^{\text {free }}: \text { unknown value }
$$

In the right-hand side of the constraint (3), the value of the variable $P C O_{o}^{\text {free }}$ is unknown and has to be assessed by the DEA model during the process of the chain efficiency measurement. The comparison of relative efficiency scores assessed by the above models -with a constraint for evaluating efficiency at the PCO level chosen by the franchisor according to its strategic vision on the chain (model 1 with constraint 2), and with a constraint for jointly evaluating the efficiency and the optimal PCO of each franchise chain (model 1 with constraint 3) -- allows us to test the hypothesis $\mathrm{H} 2$.

\subsection{Data}


The empirical study deals with the French franchise sector. We used two complementary sources for collecting data. On the one hand, the annual franchise directories published by the French Franchise Federation provide detailed information on its members such as the PCO, the size and the age of the chain, and the financial conditions associated with the franchise contract. These directories have already been used in previous research on franchising (Barthélemy, 2008; Dant et al., 2008; Perrigot, 2006). On the other hand, the DIANE database -- a product of Bureau Van Dijk Electronic Publishing -- offers financial information such as capital, labor, costs, etc. for various kinds of firms, not only in the franchise sector. It has been used in previous research dealing with French firms (Durand et al., 2008; Sentis, 2009) and French franchise chains (Barthélemy, 2008). Our sample consists of 43 franchise chains in 2007 (those present in the 2008 franchise directory) for which we had corresponding information in both databases. In this sample, 24 chains are in the retail industry (56\%), and 19 are in the services $(44 \%)$.

\subsection{Variables for the DEA models}

An important step in the DEA modeling is the identification of variables that are used to implement the benchmarking process. Variables for DEA should be chosen such that they accurately reflect the franchise chain goals, objectives, and sales situation. Resources that have a direct cost to the franchise chain are a good choice for input variables (Donthu and Yoo, 1998). We selected variables entering the DEA model in a way that is usually implemented in the DEA literature, i.e., by looking at the production process of a franchise chain. The chain is then considered as producing products based on resources. In doing so, the production of a franchise chain can be approached by total sales that is considered as a final output of the retail production process by Keh and Chu (2003) and of the service production process by Grönroos and Ojasalo (2004). The resources entering the production process can 
be defined by the capital -- the charges involved by current and previous investments, the variable costs that give an assessment of charges involved by the chain management, and the labor costs that are defined by various labor charges. Capital and labor costs are identified as raw input of the retail production process by Keh and Chu (2003) and are used by Grönroos and Ojasalo (2004) for assessing a financial measure of efficiency in the service industry. The last variable -- of particular interest in our study -- is the PCO, considered here as a synthetic indicator of plural form chains management (Dant and Kaufmann, 2003). Descriptive statistics on these variables for the 43 French franchise chains in our sample are provided in Table 1.

\section{Insert Table 1 here}

\section{Results}

\subsection{Efficiency of French franchise chains}

Table 2 provides descriptive statistics on the scores evaluated for the French franchise chains in our sample based on the three DEA models defined in the methodology section. When the efficiency score is equal to unity, the franchise chain is fully efficient. When the efficiency score is less than unity, the franchise chain is inefficient compared to the other chains of the sample. It means that it is possible to find either an efficient franchise chain -- an unique benchmark -- or various efficient franchise chains -- a set of benchmarks -- in the sample that produce the same product with a smaller amount of resources.

The average efficiency score of the franchise chains evaluated by means of the classical DEA model (model 1) is equal to 0.41 ; meaning that efficiency of franchise chains can be increased on average by 59\%. The range of the efficiency scores are between 0.18 and 1 , with a Q1-value at 0.25 and a Q3-value at 0.47 . These figures show a large dispersion of efficiency 
scores across the franchise chains in our sample. When the efficiency of franchise chains is measured by taking into account the observed PCO of the chain (model 1 with equation 2), efficiency scores are higher with an average of 0.46; meaning that the efficiency of franchise chains can be increased on average by $54 \%$. While the range of efficiency scores remains the same, the Q1- and Q3-values are also higher. Thus, it means that the PCO chosen by the franchisor induces a higher efficiency for the franchise chains -- 5\% on average, $3 \%$ at the Q1-value and 4\% at the Q3-value. This result supports hypothesis H1 stating that "The PCO chosen by the franchisor has a positive impact on its chain efficiency".

\section{Insert Table 2 here}

When the PCO is jointly determined by the DEA model during the efficiency assessment (model 1 with equation 3), franchise chains achieve lower efficiency scores than with the two other DEA models. Not being at the optimal PCO provides additional potential efficiency improvement. By comparison with the scores provided for the current PCO (model 1 with equation 2), these improvements are evaluated at $6 \%$ on average, $1 \%$ at the Q1-value, and $10 \%$ at the Q3-value; showing a higher impact of not being at the optimal PCO for franchise chains that are the most efficient with the two other DEA models. This result supports hypotheses $\mathrm{H} 2$ stating that "Higher improvements in franchise chain efficiency can be achieved when the PCO is optimized".

\subsection{Optimal values of PCO for French franchise chains}

Table 3 presents the optimal PCO values evaluated by the DEA model developed in this study. These values are then compared to the observed PCO collected in our data set. Current PCO are, on average, equal to $32.4 \%$ with a minimum of $0 \%$ (for three chains) and a maximum of $87.2 \%$. Optimal PCO values are higher, with an average value of $44.2 \%$. The minimum is close to zero $(0.6 \%)$ while the maximum is equal to $100 \%$. Chains that had an 
observed PCO of 0\% -- they were fully franchised - receive an optimal PCO strictly higher than zero; meaning that they could increase performance by owning some of their outlets. Chains that had an observed PCO equal or higher than $85 \%$ receive an optimal PCO of $100 \%$ -- they should become fully company-owned.

\section{Insert Table 3 here}

Table 3 also displays the number of franchise chains for which the franchisor should either increase or decrease the PCO in its chain in order to become more efficient. For chains that are already at their optimal PCO in the data set, i.e., two chains in our sample, it remains the same. For chains that are not at their optimal PCO, the proportion of chains which should increase their PCO is higher than the proportion of chains which should decrease it. No single direction is provided, it depends on the chain characteristics. Chain efficiency can be improved by either an increase or a decrease of the PCO for $60 \%$ and $35 \%$ of the chains, respectively.

\section{Discussion}

\subsection{Contributions to research}

This research contributes to the literature on franchising, and more specifically on efficiency in the franchise sector, on the one hand, and on the other hand, on plural form chains. In accordance with previous findings from Blair and Kaserman (1982) who found that the optimal strategy may be dependent on markets and firm characteristics and Lee (1984) who considered that the optimal number of franchisees depends on the history of the chain, our results confirm that the plural form -- measured by the percentage of company-owned outlets (PCO) -- is a variable that positively influences chain efficiency (hypothesis H1), but that the main explanation of franchise chains inefficiency has to be found in other chain 
characteristics. Indeed, the impact of the plural form on the franchise chain efficiency is only up to $5 \%$, while other characteristics have an impact evaluated at $54 \%$ on average.

Then, the study provides a modeling that allows us to answer to Shane's (1998, p. 736) question: "the correct question for franchising scholars to ask is [...] what is the optimal proportion of franchised units given other firm characteristics?". Previous literature has highlighted that the efficiency of plural form chain is influenced by the existence of an optimal proportion of franchised outlets (El Akremi et al., forthcoming; Hsu and Jang, 2009). Even though these studies identified a non-linear relationship between efficiency and PCO with a positive impact until a maximum value after which the impact become negative, they did not provide specific results for each observed franchise chain in their sample, taking into account their specific characteristics. The extended DEA model developed in this study allows us to overcome this shortcoming. Our study also shows that larger improvements in efficiency of the franchise chain can be implemented when the PCO is set at its optimal value (hypothesis H2). On average, optimal PCOs are higher than observed ones. However, there is not only one possible direction for changing of PCO in order to improve chain efficiency. Some chains do not require any change. Other chains require an increase or a decrease of their current PCO for $60 \%$ and $35 \%$ of the chains, respectively.

\subsection{Contributions to practice}

With increased competitive pressures in both retail and service industries, franchisors have greater interest in measuring the efficiency of their franchise chain relative to their main competitors -- competitive benchmarking -- or to chains in different industries -- functional benchmarking. The empirical application of this study covers both type of benchmarking, since our sample contains franchise chains in both retail and service industries. 
The benchmarking process is implemented by a Data Envelopment Analysis (DEA), a consistent methodology with (i) a logic that managers use to benchmark their own organization performance (Fitzgerald and Storbeck, 2003); (ii) theoretical viewpoints on how firms contest and compete in markets (Devinney et al., 2000), and (iii) possibilities to capture the empirical multidimensional nature of performance (Venkatramam and Ramanujam, 1986; 1987). Furthermore, DEA allows for the implementation of the three basic steps of the benchmarking process that analysts agree on (Donthu et al., 2005): (i) identifying the best performers, i.e., who to benchmark, (ii) defining benchmarking goals, and (iii) developing action plans. DEA also provides a useful support for monitoring the process and adjusting action plans over time.

Even though a literature on franchise chain efficiency exists, only a few studies are concerned with exploring the efficiency impact of strategic -- internal -- variables (Gauri, 2013) for which franchisors are responsible, as the percentage of company-owned outlets (PCO) in their chains. By developing a model that enables the joint evaluation of franchise chain efficiency and optimal PCO, this study offers to franchisors a specific benchmarking for optimizing the use of resources within the chain as well as setting their PCO at a level that maximize their efficiency.

\subsection{Limitations and tracks for future research}

Main limitations of our research first deal with the sample of franchise chains under investigation. It is quite small, including only 43 franchise chains. Even though it is comparable to the sample of companies analyzed in previous research on efficiency in the retail sector (e.g., Yu and Ramanathan (2008): 41 retail companies; Mostafa (2009): 45 retailers), a larger sample of franchise chains would be preferable in order to reinforce the validity of the results. Moreover, the empirical study deals with only one country: France. The 
exploration of franchise chain efficiency in several countries would allow for highlighting similarities and differences across different settings. Another limitation of the empirical study is that it relies on cross-sectional data. The use of a longitudinal approach would facilitate result stability checking over time. The last limitation is about the selection of variables used. Even though this selection was consistent with previous research on efficiency in the retail and service industries, other variables could be tested in future research.

\section{Conclusion}

In this paper, we explore the links between the organizational form and the efficiency of franchise chains. The main findings of our research are as follows. First, the plural organizational form of franchise chains -- characterized by the percentage of outlets owned by the franchisor -- positively influences the chain efficiency, even though their inefficiency is clearly driven by other chain characteristics. Second, the optimization of the PCO entails additional improvements of the franchise chain efficiency. When a change in the PCO is suggested for achieving a higher efficiency, it can correspond to either an increase or a decrease of the PCO; meaning that the direction of the evolution towards an optimal PCO is driven by chain characteristics. The new model developed in this study enables the implementation a new benchmarking process, taking into account the existence of a strategic variable for which franchisors are responsible -- the PCO characterizing the plural organizational form of franchise chains -- that impacts the efficiency of the chain. The model based on Data Envelopment Analysis evaluates the level of efficiency that can be achieved by setting the strategic variable at the optimal level of each franchise chain. As the study only considers one country and one year, more research is needed for validating the model in other contexts and environments. 


\section{References}

Anderson, E.E. (1984), "The Growth and Performance of Franchise Systems: Company Versus Franchisee Ownership", Journal of Economics and Business, Vol. 36 No . 4, pp. 421-431.

Anderson, R.I., Fok, R. and Scott, J. (2000), "Hotel industry efficiency: An advanced linear programming examination", American Business Review, Vol. 18 No. 1, pp. 40-48.

Anderson, R.I., Fok, R., Zumpano, L.V. and Elder, H.W. (1998), "The efficiency of franchising in the residential real estate brokerage market", Journal of Consumer Marketing, Vol. 15 No. 4, pp. 386-396.

Banker, R.D., and Morey, R. (1986), "Efficiency analysis for exogenously fixed inputs and outputs", Operations Research, Vol. 34 No. 4, pp. 513-521.

Barros, C.P. (2006), "Efficiency measurement among hypermarkets and supermarkets and the identification of the efficiency drivers: A case study", International Journal of Retail \& Distribution Management, Vol. 34 No. 2, pp. 135-154.

Barros, C.P. and Alves, C.A. (2003), "Hypermarket Retail Efficiency in Portugal". International Journal of Retail \& Distribution Management, Vol. 31 No. 11, pp. 549-560.

Barthélemy, J. (2008), "Opportunism, knowledge and the performance of franchise chains", Strategic Management Journal, Vol. 29 No. 13, pp. 1451-1463.

Blair, R.D. and Kaserman, D.L. (1982), “Optimal franchising”, Southern Economic Journal, Vol. 49 No. 2, pp. 494-504.

Botti, L., Briec, W. and Cliquet, G. (2009), "Plural forms versus franchise and companyowned systems: A DEA approach of hotel chain performance", Omega, Vol. 37 No. 3, pp. 566-578.

Bradach, J.L. (1997), "Using the plural form in the management of restaurant chains", Administrative Science Quarterly, Vol. 42 No. 2, pp. 276-303.

Bradach, J.L. (1998), Franchise Organizations, Harvard Business School Press, Boston.

Bradach, J.L. and Eccles, R.G. (1989), "Price, Authority and Trust: From Ideal Types to Plural Forms", Annual Review of Sociology, Vol. 15, pp. 97-118.

Caves, R.E. and Murphy, W.F. (1976), "Franchising: Firms, markets and intangible assets", Southern Economic Journal, Vol. 42 No. 4, pp. 572-586.

Charnes, A., Cooper, W.W., Lewin, A.Y., and Seiford, L.M. (1994), Data Envelopment Analysis: Theory, Methodology, and applications. Boston: Kluwer.

Charnes, A.W., Cooper, W.W. and Rhodes, E. (1978), "Measuring the efficiency of decision making units", European Journal of Operational Research, Vol. 2 No. 6, pp. 429-444.

Cliquet, G. (2000), "Plural forms in store networks: A proposition of a model for store network evolution", International Review of Retail, Distribution and Consumer Research, Vol. 10 No. 4, pp. 369-387. 
Combs, J.G., Ketchen, D.J., Shook, C.L. and Short, J.C. (2011a), "Antecedents and consequences of franchising: Past accomplishments and future challenges", Journal of Management, Vol. 37 No. 1, pp. 99-126.

Combs, J. G., Ketchen, D.J.Jr. and Short, J.C. (2011b), "Franchising Research: Major Milestones, New Directions, and Its Future Within Entrepreneurship", Entrepreneurship Theory and Practice, Vol. 35 No. 3, pp. 413-425.

Dant, R.P. and Kaufmann, P.J. (2003), "Structural and strategic dynamics in franchising", Journal of Retailing, Vol. 79 No. 2, pp. 63-75.

Dant, R.P., Perrigot, R. and Cliquet, G. (2008), "A Cross-cultural comparison of the plural forms in franchise chains: USA, France, and Brazil", Journal of Small Business Management, Vol. 46 No. 2, pp. 286-311.

de Jorge Moreno, J. (2008), "Efficiency and regulation in Spanish hypermarket retail trade: A cross-section approach", International Journal of Retail \& Distribution Management, Vol. 36 No. 1, pp. 71-88.

de Jorge Moreno, J. and Sanz-Triguero, M. (2011), "Estimating technical efficiency and bootstrapping Malmquist indices: Analysis of Spanish retail sector”, International Journal of Retail \& Distribution Management, Vol. 39 No. 4, pp. 272-288.

Devinney, T.M., Midgley, D.F. and Venaik, S. (2000), "The Optimal Performance of the Global Firm: Formalizing and Extending the Integration Responsiveness Framework", Organization Science, Vol. 11 No. 6, pp. 674-695.

Donthu, N. and Yoo, B. (1998), "Retail Productivity Assessment Using Data Envelopment Analysis", Journal of Retailing, Vol. 74 No. 1, pp. 89-105.

Donthu, N., Hershberger, E.K. and Osmonbekov, T. (2005), "Benchmarking Marketing Productivity using Data Envelopment Analysis", Journal of Business Research, Vol.58 No. 11, pp. 1474-1482.

Durand, R., Bruyaka, O. and Mangematin, V. (2008), "Do science and money go together? The case of the French biotech industry", Strategic Management Journal, Vol. 29 No. 12, pp. 1281-1299.

Ehrmann, T. and Spranger, G. (2004), "Successful franchising using the plural form", in Windsperger, J., Cliquet, G., Hendrikse, G. and Tuunanen, M. (Eds.), Economics and Management of Franchising Chains, Physica-Verlag, Heidelberg, pp. 89-108.

El Akremi, A., Perrigot, R. and Piot-Lepetit, I. (2013), "Examining the drivers for franchised chains performance through the lens of the dynamic capabilities approach", Journal of Small Business Management, online.

Fitzgerald L. and Storbeck J. (2003), "Pluralistic Views of Performance", Management Decision, Vol.41 No. 8, pp. 741-750.

Gauri, D.K. (2013), "Benchmarking retail productivity considering retail pricing and Format strategy", Journal of Retailing, Vol. 89 No. 1, pp. 1-14. 
Grönroos, C. and Ojasalo, K. (2004), "Service productivity - Towards a Conceptualization of the Transformation of Inputs into Economic Results in Services", Journal of Business Research, Vol. 57 No. 4, pp. 414-423.

Hsu, L-T. and Jang, S. (2009), "Effects of restaurant franchising: Does an optimal franchise proportion exist?", International Journal of Hospitality Management, Vol. 28 No. 2, pp. 204-211.

Hunt, S.D. (1973), “The Trend Toward Company-Operated Units in Franchise Chains", Journal of Retailing, Vol. 49 No. 2, pp. 3-12.

Keh, H.T. and Chu, S. (2003), "Retail Productivity and Scale Economies at the Firm Level: a DEA approach”, Omega, Vol. 31 No. 2, pp. 75-82.

Kosová, R., Lafontaine, F. and Perrigot, R. (2013), “Organizational Form and Performance: Evidence from the Hotel Industry", The Review of Economics and Statistics. Vol. 95 No. 4, pp. 1303-1323.

Lafontaine, F. and Shaw, K.L. (2005), "Targeting managerial control: Evidence from franchising”, The RAND Journal of Economics, Vol. 32 No. 1, pp.131-150.

Lee, W.L. (1984), "Franchising and interbrand competition", Southern Economic Journal, Vol. 51 No. 1, pp. 219-234.

Michael, S.C. (1996), "To franchise or not to franchise: An analysis of decision rights and organizational form shares”, Journal of Business Venturing, Vol. 11 No. 1, pp. 57-71.

Michael, S.C. (2000), "Investments to create bargaining power: The case of franchising", Strategic Management Journal, Vol. 21 No. 4, pp. 497-514.

Mostafa, M.M. (2009), Benchmarking the US specialty retailers and food consumer stores using data envelopment analysis, International Journal of Retail \& Distribution Management, Vol. 37 No. 8, pp. 661-679.

Oxenfeldt, A.R. and Kelly, A.O. (1968-69), "Will Successful Franchise Systems Eventually Become Wholly-Owned Chains?”, Journal of Retailing, Vol. 44 No. 4, pp. 69-83.

Perrigot, R. (2006), "Service vs. Retail chains: are there any differences? Evidence from the French franchising Industry", International Journal of Retail \& Distribution Management, Vol. 34 No. 12, pp. 918-930.

Perrigot, R., Cliquet, G. and Piot-Lepetit, I. (2009), "Plural form chain and efficiency: Insights from the French hotel chains and the DEA methodology", European Management Journal, Vol. 27 No. 4, pp. 268-280.

Perrigot, R. and Herrbach, O. (2012), "The plural form from the inside: A study of franchisees' perceptions about the existence of company-owned outlets within their network", International Journal of Retail \& Distribution Management, Vol. 40 No. 7, pp. 544-563. 
Perryman, A.A. and Combs, J.G. (2012), "Who Should Own it? An Agency-Based Explanation for Multi-Outlet Ownership and Co-Location in Plural Form Franchising", Strategic Management Journal, Vol. 33 No. 4, pp. 368-386.

Scott, F.A. (1995), "Franchising vs. company-ownership as a decision variable for the firm", Review of Industrial Organization, Vol. 10 No. 11, pp. 69-81.

Sellers-Rubio, R., Mas-Ruiz, F. (2006), "Economic efficiency in supermarkets: evidences in Spain”, International Journal of Retail \& Distribution Management, Vol. 34 No. 2, pp. 155-171.

Sentis, P. (2009), "Insider trading, pricing and the long-run performance of IPOs: Evidence from the French market during the high-tech bubble", Venture Capital, Vol. 11 No. 2, pp. 107-132.

Shane, S. (1998), "Explaining the distribution of franchised and company-owned outlets in franchise systems", Journal of Management, Vol. 24 No. 6, pp. 717-739.

Tsaur, S.H. (2000), "The operating efficiency of international tourist hotels in Taiwan", Asia Pacific Journal of Tourism Research, Vol. 6 No. 1, pp. 29-37.

Uyar, A., Bayyurt, N., Dilber, M. and Karaca, V. (2013), "Evaluating operational efficiency of a bookstore chain in Turkey and identifying efficiency drivers", International Journal of Retail \& Distribution Management, Vol. 41 No. 5, pp. 331-347.

Venkatramam N. and Ramanujam V. (1986), "Measurement of Business Performance in strategy Research: A Comparison of Approaches", Academy of Management Review, Vol. 11 No. 4, pp. 801-814.

Venkatramam N. and Ramanujam V. (1987), "Measurement of Business Economic Performance: An Examination of Method Convergence", Journal of Management, Vol. 13, pp. 109-122.

Yoo, B., Donthu, N. and Pilling, B.K. (1998), "Channel efficiency: Franchise vs. nonfranchise systems", Journal of Marketing Channels, Vol. 6 No. 3/4, pp. 1-15.

$\mathrm{Yu}, \mathrm{W}$. and Ramanathan, R. (2008), "An assessment of operational efficiencies in the UK retail sector”, International Journal of Retail \& Distribution Management, Vol. 36 No. 11, pp. 861-882. 
Tables

Table 1. Descriptive statistics of DEA variables (43 franchise chains)

\begin{tabular}{lrrrr}
\hline & \multicolumn{1}{c}{ Mean } & \multicolumn{1}{c}{ Std-dev } & \multicolumn{1}{c}{ Min } & \multicolumn{1}{c}{ Max } \\
\hline Output $(\mathrm{k} €)$ & & & & \\
$\quad$ Total sales & 175,052 & 581,261 & 1,728 & $3,488,683$ \\
Inputs $(\mathrm{k} €)$ & & & & \\
$\quad$ Capital & 9,182 & 21,565 & 26 & 62,837 \\
$\quad$ Labor costs & 28,771 & 62,880 & 306 & 322,096 \\
$\quad$ Variable costs & 54,568 & 124,142 & 639 & 533,493 \\
Strategic input $(\%)$ & & & & \\
$\quad$ PCO & 0.32 & 0.30 & 0 & 0.87 \\
\hline
\end{tabular}

Table 2. Descriptive statistics of efficiency scores (43 franchise chains)

\begin{tabular}{lllllll}
\hline \multicolumn{7}{c}{ Efficiency measurement - French franchise chains } \\
\hline DEA model with: & Mean & Std-dev & Min & $Q 1$ & $Q 3$ & Max \\
\hline No PCO & 0.4087 & 0.2299 & 0.1816 & 0.2553 & 0.4698 & 1 \\
Current PCO & 0.4584 & 0.2647 & 0.1816 & 0.2839 & 0.5142 & 1 \\
Optimal PCO & 0.3955 & 0.2230 & 0.1816 & 0.2706 & 0.4136 & 1 \\
\hline
\end{tabular}

Table 3. Descriptive statistics of current and optimal PCO (43 franchise chains)

\begin{tabular}{lcccccc}
\hline \multicolumn{7}{c}{ Current and optimal PCO - French franchise chains } \\
\hline PCO: & Mean & Std-dev & Min & $Q 1$ & $Q 3$ & Max \\
\hline Current PCO & 0.3244 & 0.2898 & 0 & 0.0642 & 0.6112 & 0.8722 \\
Optimal PCO & 0.4426 & 0.3776 & 0.0061 & 0.1185 & 0.8491 & 1 \\
Changes in PCO & \multicolumn{2}{c}{ Increase } & \multicolumn{2}{c}{ Decrease } & \multicolumn{2}{c}{ No change } \\
& $n b$ & $\%$ & $n b$ & $\%$ & $n b$ & $\%$ \\
Franchise chains & 26 & 60 & 15 & 35 & 2 & 5 \\
\hline
\end{tabular}

